\title{
Article \\ Correlating Structure and Morphology of Andiroba Leaf (Carapa guianensis Aubl.) by Microscopy and Fractal Theory Analyses
}

\author{
Robert S. Matos ${ }^{1,2,3, *}$ (D) Ştefan Ţălu ${ }^{4, *}\left(\mathbb{D}\right.$, Gunar V. S. Mota ${ }^{5}\left(\mathbb{D}\right.$, Erveton P. Pinto ${ }^{2}{ }^{(}$, Marcelo A. Pires ${ }^{6}$, \\ Leida G. Abraçado ${ }^{6}$ and Nilson S. Ferreira ${ }^{3,7}$ (D) \\ 1 Postgraduate Program in Materials Science and Engineering (P2CEM), Federal University of Sergipe, \\ São Cristovão 49100-000, SE, Brazil \\ 2 Amazonian Materials Group, Physics Department, Federal University of Amapá, \\ Macapá 68903-419, AP, Brazil; erveton@unifap.br \\ 3 Laboratory of Corrosion and Nanotechnology (LCNT), Federal University of Sergipe, \\ São Cristovão 49100-000, SE, Brazil; nilsondsf@gmail.com \\ 4 The Directorate of Research, Development and Innovation Management (DMCDI), \\ Technical University of Cluj-Napoca, 15 Constantin Daicoviciu St., 400020 Cluj-Napoca, Romania \\ 5 Natural Science Faculty, UFPA, ICEN, Belém 66075-110, PA, Brazil; gunarmota@yahoo.com \\ 6 Brazilian Center for Research in Physics (CBPF), Rio de Janeiro 22290-180, RJ, Brazil; \\ pires.ma.fisica@gmail.com (M.A.P.); leidaabracado@hotmail.com (L.G.A.) \\ 7 Department of Physics, Federal University of Sergipe, São Cristovão 49100-000, SE, Brazil \\ * Correspondence: amazonianmaterialsgroup@gmail.com (R.S.M.); stefan_ta@yahoo.com (Ş.T.̧.)
}

Citation: Matos, R.S.; Ţălu, Ş.; Mota, G.V.S.; Pinto, E.P.; Pires, M.A.; Abraçado, L.G.; Ferreira, N.S. Correlating Structure and Morphology of Andiroba Leaf (Carapa guianensis Aubl.) by Microscopy and Fractal Theory Analyses. Appl. Sci. 2021, 11, 5848. https://doi.org/10.3390/app11135848

Academic Editor: Theodore

E. Matikas

Received: 6 June 2021

Accepted: 21 June 2021

Published: 23 June 2021

Publisher's Note: MDPI stays neutral with regard to jurisdictional claims in published maps and institutional affiliations.

Copyright: (C) 2021 by the authors. Licensee MDPI, Basel, Switzerland. This article is an open access article distributed under the terms and conditions of the Creative Commons Attribution (CC BY) license (https:// creativecommons.org/licenses/by/ $4.0 /)$.

\begin{abstract}
The Amazon rainforest is considered a megadiverse biome, where several species of its rich flora are still unknown. The anatomy of their leaves usually identifies species. In this paper, we present a complete characterization of the leaf surface of Amazon Carapa guianensis Aubl. (Andiroba), using microscopy and fractal theory to be considered a possible tool for investigating different leaves spatial patterns, especially in species with similar leaf architecture. The SEM results revealed the cellular structures and other non-cellular structures that make up the leaf architecture, both for the abaxial and adaxial sides. The cells responsible for the plant photosynthesis process were observed in the internal structure of the leaf. The wettability analysis showed that the abaxial side is more hydrophobic, while the adaxial side is more hydrophilic. AFM images exposed the relevant details of the microstructure of the leaf abaxial side, such as stomata, pores, furrows, contour, particles, and rough profiles generated by topographic irregularities. The statistical parameters revealed that the scale size influences the topographic roughness, surface asymmetry, and shape of the height distribution, also observed by advanced parameters obtained according to the standard of the international organization for standardization (ISO). The fractal and advanced fractal parameters confirmed changes in spatial patterns as a function of scale size. The largest area exhibited greater spatial complexity, low dominant spatial frequencies, more excellent surface percolation, intermediate topographic homogeneity, and high uniformity of spatial patterns.
\end{abstract}

Keywords: Andiroba; leaves surface; microscopy; ISO parameters; fractal parameters

\section{Introduction}

The Amazon rainforest is a gigantic biome whose diversity of fauna and flora has not yet been precisely measured. The immense diversity of flora has led to the commercial exploitation of some species, mainly due to the local commerce in the region that comprises northern Brazil [1]. Trade in species in this region has intensified due to the fight against deforestation in the Amazon region [2]. Moreover, the protection and preservation of the forest have become the precursor concepts of motivation for the sustainable use of Amazonian biodiversity [3]. 
Among the plants sold in this region, Carapa guianensis Aubl., popularly known as "Andiroba" has been highlighted by the diversified use of oil extracted from its seeds [4]. It is a species of the Meliaceae family, which is quickly found in floodplain regions (Várzea) in the Amazon rainforest [5]. Some works have reported several therapeutic potentials of this plant, such as acaricide [6], larvicide [7], antiallergic [5], anti-inflammatory [5], and antimicrobial [8]. However, the main use of this plant has still been by logging, which is currently growing in the Amazon [9].

Andiroba is a large tree, and its seeds are often commercialized to extract Andiroba oil [10]. Due to the need to absorb a large amount of water to maintain their metabolism, it is not easy to find this species in other regions that differ from floodplain forests in the Amazon rain forest. Moreover, this may be related to the species' survival strategy, as it uses the tidal system to spread its seeds over kilometers of distance [11], using the Amazon rivers.

Furthermore, although under relatively adverse weather conditions, this species has survived without any apparent change over time. It is known that as a strategy for coping with unfavorable climate conditions, some plants can change their leaf architecture to survive [12]. In addition, leaf architecture can be a helpful tool for information about the plant's anatomy [13]. Notably, the study of leaf architecture can be of great value in identifying the effect of light conditions, seasons, and climate in general that can modify leaf structures (cells) to understand the plant's survival requirements. As there are still many unknown species in the Amazon rainforest, the anatomy of the leaf can be a faster way to identify the different species [14], including those whose anatomy is very similar and difficult to identify by traditional methods. In addition, leaf architecture can also reveal specific behavior concerning plant wettability that can help the development of technological products, as has recently been made for bamboo surface-based lotus leaf [15], Portland cement surface-based lotus leaf [16], and magnesium alloy AZ31 surface-based lotus leaf [17].

The identification of spatial patterns of leaves by microscopy techniques, mainly using atomic force microscopy (AFM) measurements, has been explored recently, e.g., [18-20]. This has been done with the support of parameters based on fractal theory [21-25], power spectrum density (PSD) $[18,22,26]$, and those based on the International Organization for Standardization (ISO) standard [27-29]. However, a relationship between spatial patterns and scale size dependence has not yet been discussed, as it is known that at least height parameters, such as roughness, skewness, and kurtosis, have a behavior that depends on the evaluated area because the distribution and quantity of particles on the surface can promote the appearance of different height profiles.

For all these reasons, we studied the 3D micromorphology of Andiroba leaf using scanning electron microscopy (SEM), atomic force microscopy (AFM), and fractal theory. The main goal of this paper was to understand how the leaf architecture is structured according to the scale size, to map the unique spatial patterns of the leaf. For this purpose, ISO 25178-2: 2012 and fractal parameters of their micromorphology were taken from the topographic maps of AFM. The results have revealed that the spatial patterns of the leaf abaxial side have a scale-dependence behavior, suggesting that leaf surface spatial complexity can play an important role in identifying this and other species.

\section{Materials and Methods}

\subsection{Material}

The Andiroba (Carapa guianensis Aubl.) leaves were collected in the Mazagão Velho city, State of Amapá, Brazil.

\subsection{SEM Measurements}

Before analyzing the images, the Andiroba leaf samples were freeze-dried ( $24 \mathrm{~h}$ at $-60^{\circ} \mathrm{C}$ ). Afterward, these samples were fixed in double-sided carbon adhesive tape with- 
out coating in a conventional $\mathrm{Al}$ stub and analyzed using a scanning electron microscope (SEM, HitachiE-1010, Japan) operating in the range $25 \mathrm{kV}$ to $50 \mathrm{kV}$.

\subsection{AFM Imaging and 3D Micromorphology Evaluation}

The topographies of the Andiroba leaves were analyzed by atomic force microscopy (AFM) using an INTEGRA NT-MDT. The scanning was performed in tapping mode using a tip scanner with a radius of curvature of $10 \mathrm{~nm}$. The calibration parameters (tip resonance frequency, phase, amplitude, and gain) were varied for each leaf sample. To analyze the dependence between topographical parameters and scale size, images of three different sizes $(50 \times 50 \mu \mathrm{m}, 20 \times 20 \mu \mathrm{m}$, and $10 \times 10 \mu \mathrm{m})$, whose samples were labeled S50, S20, and $\mathrm{S} 10$ obtained from the side where the stomata were present (abaxial) were analyzed. For each size, four different images of random regions of the surface were taken to obtain the mean values of the calculated topographic parameters. The topographical images analyze and the computation of four height parameters (average roughness $R_{a}$, root mean square roughness $R_{R M S}$, surface skewness $S_{S}$ and surface kurtosis $K_{S}$ ), selected according to Bobrovskij [30] were performed using WsxM free software [31]. The ISO parameters and the qualitative renderings of the leaf microtexture were obtained by MountainsMap Premium software trial version 8.4.8872 [32], according to ISO 25178-2:2012.

\subsubsection{Power Spectrum Density Analysis}

The PSD changes the AFM image into the frequency domain using Fourier transform and exposes the distribution of surface heights in terms of wave vectors. In addition, the dominant wavelengths contributing to the topography of the surface and lateral correlation length between surface heights can be computed from PSD [33]. Fractal region of onedimensional PSD was estimated according to Equation (1) using WSxM@ 5.0 software, where Lx is the pixels/line in an image, $h(x, y)$ is the height values of AFM topographic maps, and $q_{x}$ is the wave vector $[33,34]$ :

$$
\operatorname{PSD}^{1 D}\left(q_{x}\right)=L_{x}^{-1}\left[\int_{L_{x}} h(x, y) e^{-i q_{x} x} d x\right]^{2}
$$

From obtained PSD spectrum, a linearized curve was used to compute the Hurst coefficient quantitative parameter using Equation (2) [33]:

$$
\mathrm{H}=\frac{\alpha-2}{2}
$$

where $\alpha$ is the absolute curve slope. This parameter is associated with the dominant wavelength, which is related to the signal quality emitted by the surface.

\subsubsection{Advanced Fractal Analysis}

The fractal theory has been extensively applied to study the behavior of surface morphology obtained by the AFM technique, e.g., [35,36]. For a complete quantitative assessment of the fractal geometry of the leaf, four statistical parameters were computed, such as fractal dimension (FD), surface entropy (E), fractal succolarity (FS), and fractal lacunarity (FL), using AFM images. The FD is a direct measure of the spatial complexity (irregularities) of a natural fractal object. The FD of a set is a value that tells how densely a set occupies the metric space in which it exists. Such measure was calculated using the free software Gwyddion version 2.55 [37], as made similarly in Gao et al. [38]. Additionally, FL was obtained for a complimentary evaluation of the surface microtexture. FL is a measure that relates the object's geometry to the quality of the texture [39]. The model used to obtain the lacunarity distribution was developed according to the recent study reported by 
Talu et al. [40]. The quantitative parameter studied was the lacunarity coefficient $\beta$, which was determined according to the power law of Equation (3) [40].

$$
\mathrm{L}(\mathrm{r})=\gamma \cdot \mathrm{r}^{-\beta}
$$

In order to obtain an answer on the fractal succolarity, the FS was measured. This parameter measure directly quantifies the degree of surface percolation of the analyzed surface by evaluating the connectivity between the upper and lower bands of the surface. This measure was calculated according to Equation (4) [41], using the algorithm programmed in R language developed by Pinto et al. [42].

$$
\mathrm{FS}(\mathrm{T}(\mathrm{k}), \operatorname{dir})=\frac{\sum_{\mathrm{k}=1}^{\mathrm{n}} \mathrm{P}_{0}(\mathrm{~T}(\mathrm{k})) \cdot \mathrm{PR}\left(\mathrm{T}(\mathrm{k}), \mathrm{p}_{\mathrm{c}}\right)}{\sum_{\mathrm{k}=1}^{\mathrm{n}} \operatorname{PR}\left(\mathrm{T}(\mathrm{k}), \mathrm{p}_{\mathrm{c}}\right.}
$$

where dir is the direction of the water inlet, $\operatorname{Po}(\mathrm{T}(\mathrm{k}))$ is occupation percentage to boxes of size $\mathrm{T}(\mathrm{K}), \mathrm{PR}$ is the pressure exerted by the water in the center $(\mathrm{pc})$ of the box.

\subsubsection{Uniformity Analysis}

Fundamentally, the formation of surfaces is embedded with randomness. We can apply Shannon's entropy for a given probability set related to the surface based on such an assumption. Following $[43,44]$, we evaluate the information-theory-based entropy with a binless approach:

$$
\mathrm{E}^{(\mathrm{u})}=-\sum_{\mathrm{i}=1}^{\mathrm{N}} \sum_{\mathrm{j}=1}^{\mathrm{N}} \mathrm{p}_{\mathrm{ij}} \cdot \log \mathrm{p}_{\mathrm{ij}}
$$

where the superscripts $u$ means unnormalized, and $p_{i j}$ is the probability of a pixel located at $\{i, j\}$ belongs to the set of outliers in the height distribution. Afterward, we compute

$$
\mathrm{E}=\frac{E^{(u)}-E_{\min }^{(u)}}{E_{\max }^{(u)}-E_{\min }^{(u)}}
$$

where $E_{\max }^{(u)}$ and $E_{\min }^{(u)}$ are terms used to normalize and centralize Equation (2), which enables a reliable comparison between different samples. The interpretation of any entropic measure requires caution; thus, we emphasize that Equation (6) is not embedded with a thermodynamic content in the field of topographic analysis. This is in contrast with other entropic approaches in tribology [45]. Despite that, Equation (7) is a global measure that provides valuable information in terms of spatial analysis: it enables assessing the spatial uniformity of the asperities over the topography.

Complementarily, we can evaluate the local uniformity. We borrow a site-to-site approach from other fields that use image analysis [46-48]. Explicitly, we compute local RMS (LRMS) distribution

$$
\operatorname{LRMS}(x, y)=\sqrt{\frac{1}{n} \sum_{x, y} h_{(x, y)}^{2}}
$$

where $n=9$, meaning that we need to compute the sum considering the focal pixel $p$ at $(x, y)$ and its Moore neighborhood (set of 8 surrounding pixels that share a vertex or edge with $p$ ). The fraction of outliers $\left(\mathrm{f}_{\text {out }}\right)$ in the $\operatorname{LRMS}(x, y)$ distribution is the local uniformity measure that informs the proportion of local asperities that differs significantly from the whole set of asperities over the surface. We develop scripts in the $R$ programming language for estimating the global and the local uniformity measures. The standard boxplot method [49] was applied to carry out an outlier analysis when necessary.

\subsection{Water Contact Angle Obtention}

The contact angles of $2 \mu \mathrm{L}$ distilled water droplets on the Andiroba leaf were measured using a Ramé Hart goniometer, Jersey city, NJ, USA, 500. We have analyzed three different 
places of the leaf surface, and an average value was determined. The roughness factor $R_{f}$ was calculated according to Equation (1), where $P_{A}$ is total surface area of the rough surface and $\mathrm{I}_{\mathrm{A}}$ is projected area of the rough surface or the footprint of the total surface area [50].

$$
\mathrm{R}_{\mathrm{f}}=\frac{\mathrm{I}_{\mathrm{A}}}{\mathrm{P}_{\mathrm{A}}}
$$

\subsection{Statistical Analysis}

All statistical analyses were performed using Past free software version 4.02. Variance analysis (ANOVA) was applied with a Tukey-test considering a $p$-value of 0.05 .

\section{Results and Discussion}

\subsection{SEM Analysis}

Figure 1 shows images of the abaxial and adaxial sides of the epidermal surface of the Andiroba leaf. The presented set of images highlights the morphological difference between the sides. As can be seen, the abaxial side (Figure 1a-c) contained the structures expected for the taxonomy of this plant, explicitly, stomach cells, while the abaxial side (Figure 1d-f) exhibits a more striated tissue. Both leaf sides may contain all plant cells, but here only the abaxial side was observed, the stomata, which might be related to the climatic dynamics of the Amazon rainforest. This absence of stomach cells is typical behavior that has been reported for the adaxial side of Nepenthes species [51].

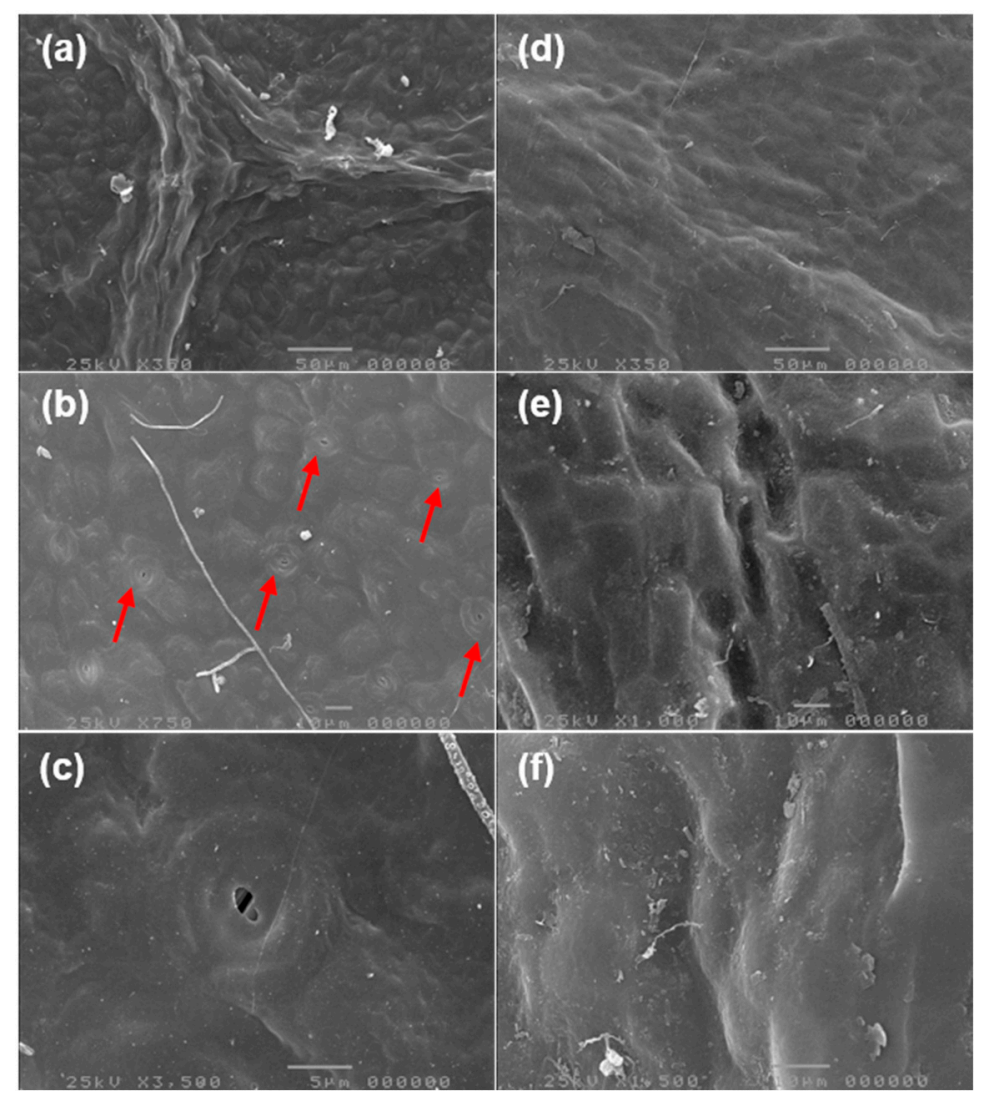

Figure 1. SEM images of Andiroba leaf surface. The following magnifications were applied: (a) $\times 350$, (b) $\times 750$, and (c) $\times 3500$ for Abaxial side and (d) $\times 350,(\mathbf{e}) \times 1000$, and $(\mathbf{f}) \times 1500$ for Adaxial side.

The stomata in the abaxial side, highlighted by the red arrows (Figure 1b), are cells specialized in gas exchange with the medium [52,53]. These cells are separated by polygonal structures formed by clusters of common epidermal cells, as can be noted in Figure 1a. In the stomata pore (Figure 1c), we can see a slit that allows gases to enter and exit; hence it 
also controls the water outlet [54]. Figure 1e,f, show the clustering of typical epidermal cells that form the epidermal tissue on the adaxial side. The thicker tissue provides additional protection against constant rainfall changes in the Amazon region. The environment in which the leaves were harvested most likely results in differences in the composition of the epidermis. In fact, in the Amazon rainforest, climate change can occur suddenly [55], where variations in temperature and water vapor in the forest can shift stomach cells, preferably for the abaxial part. The organic matter present on the forest floor can be a constant emitter of carbon dioxide [56], explaining the absence of stomach cells on the adaxial side. Moreover, the increasing fires in the Amazon may be providing an evolutionary mechanism to this plant, changing its leaf structure.

More details of the microstructure of the leaf for both sides are shown in Figure 2, where, especially, Trichomes (leaf hairs) can be observed. Such cells (highlighted by white arrows in Figure $1 \mathrm{a}, \mathrm{b}$ ) are elongated and appear on both sides, suggesting that both leaf sides can have a protection mechanism against ultraviolet radiation [57], mainly on the adaxial side. Furthermore, these cells are specialized in expelling plant substances such as soap and water that helping against insect pests [58] and be a physical barrier against the weather. Additionally, Figures $1 \mathrm{c}$ and $2 \mathrm{~d}$ revealed epicular wax, a widespread resin in plant leaves $[59,60]$. The highest magnification obtained for the abaxial side Figure $2 c$ shows a piece of the epicular wax that was removed to reveal the microstructure of the leaf. The presence of epicular wax in the leaf regulates the process of water loss and creates a barrier against toxic aerosol particles. It is also worth noting that this wax was not noticed around the pore, which was also observed for Anacardium occidentale L. leaves [53].

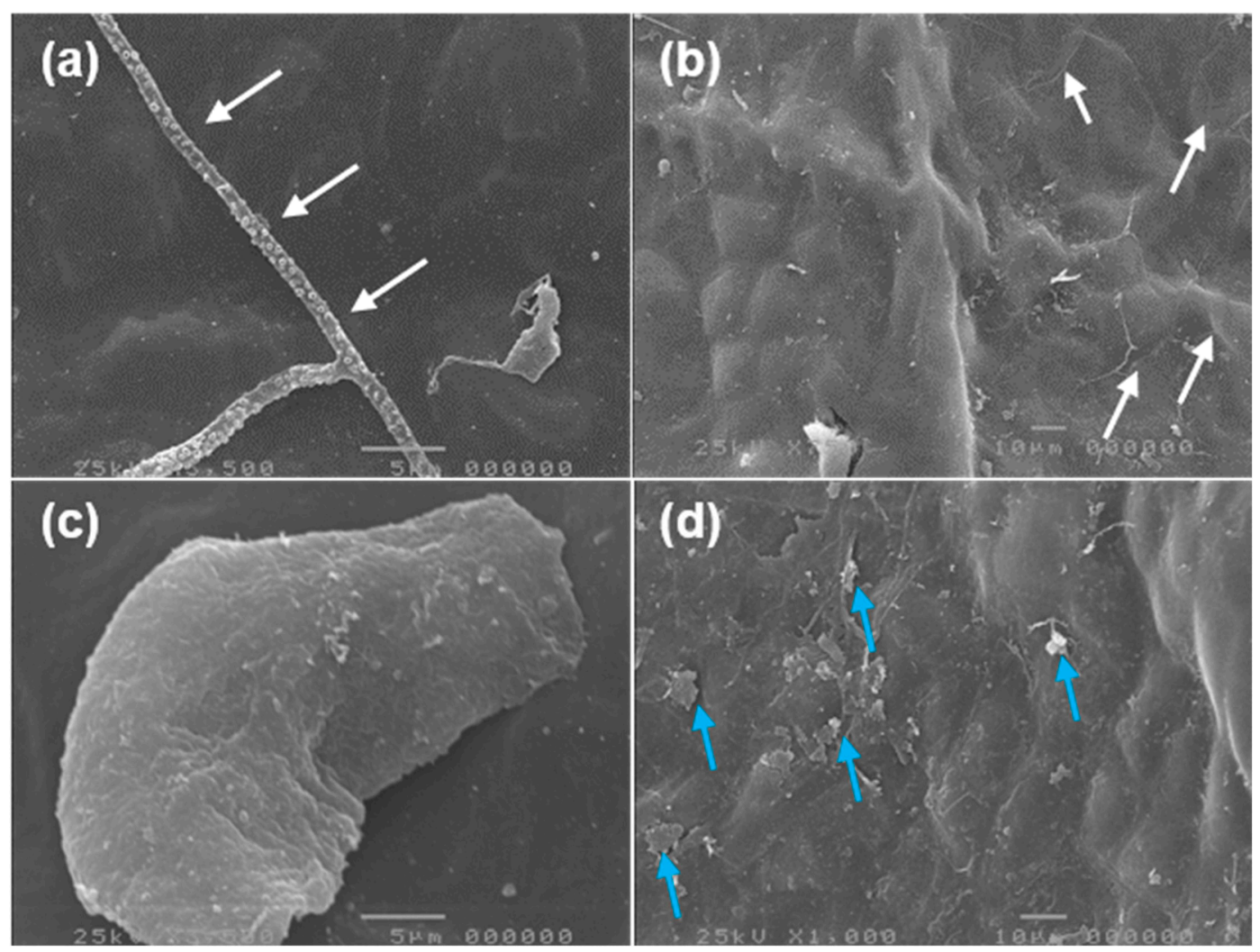

Figure 2. SEM micrographs of the abaxial and adaxial side of the Andiroba leaf surface reveal (a,b) Trichomes and (c,d) epicuticular waxes for abaxial and adaxial sides, respectively.

Figure 3 shows the main cells found along with the profile regarding the internal structure of the leaf. The main structures found in the mesophyll are the palisade parenchyma, lacunous parenchyma, xylem, and phloem, which are structures responsible for plant photosynthesis $[61,62]$. The yellow arrows in Figure $3 a, b$ highlight the watery parenchyma, 
while the red arrow in Figure 3a highlights the palisade parenchyma. The leaf structures are divided into xylem (green arrows) and phloem (purple arrows) in the core. The highresolution image in Figure $3 \mathrm{c}$ allowed us to observe that the phloem is thicker than the xylem. In addition, these structures have reticulate or net venation, which can be seen in the numerous branches of the phloems in Figure 3a, showing a unique feature of Dicotyledons species [63].
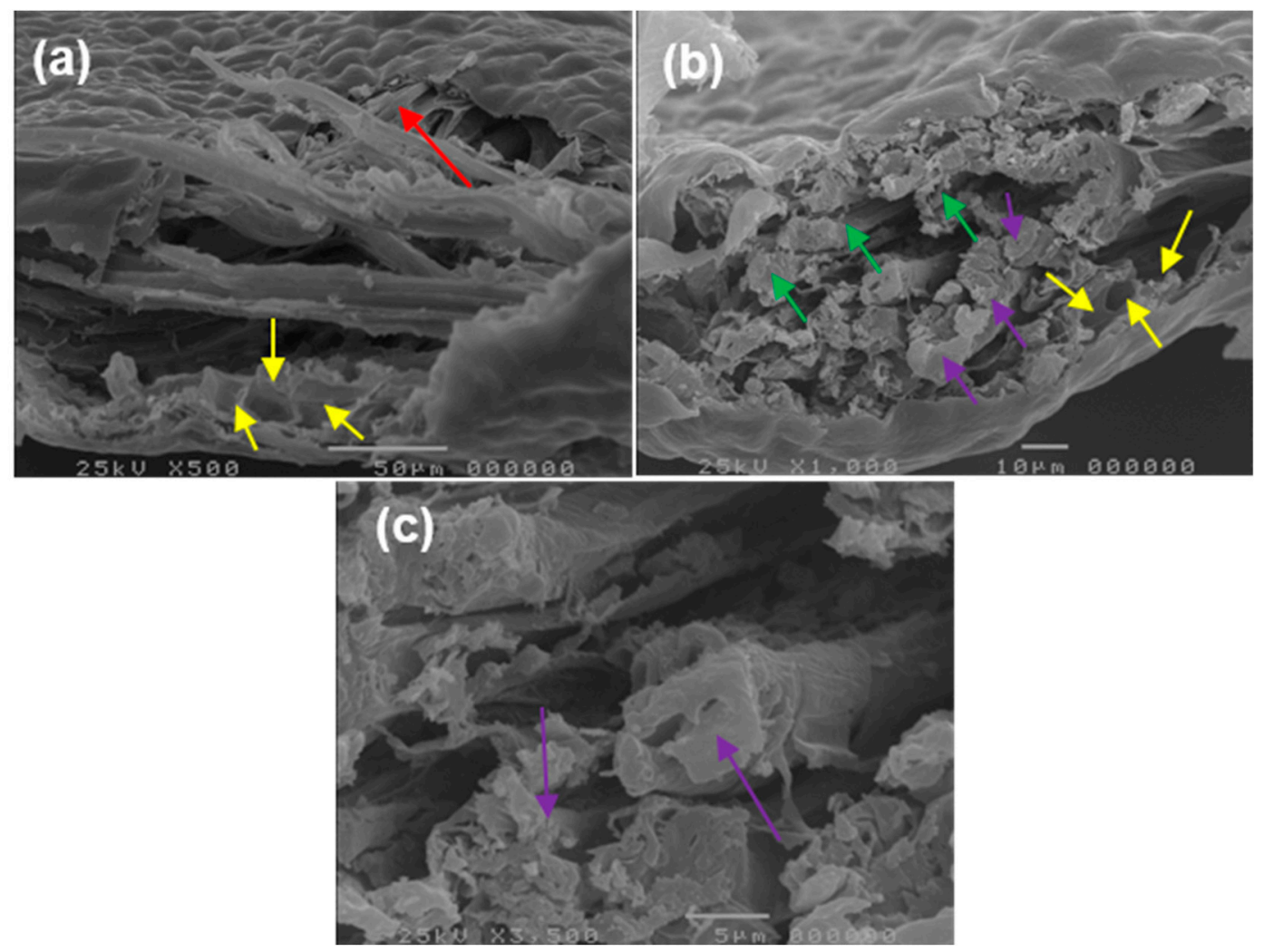

Figure 3. SEM images of cross-section cut of the leaf. (a) $\times 500,(\mathbf{b}) \times 1000$, and (c) $\times 3500$.

In the Amazon rainforest, it is common to find this tree on the banks of the Floodplain Rivers. Its seeds are dispersed by the tidal system of the Amazon river [64], over distances that can reach up to $8.7 \mathrm{~km}$ [11], which can promote good reforestation in other regions of the same ecosystem. As the cellular structures of a plant's leaf are responsible by various chemical and physical processes of the leaf, mainly photosynthesis [65], he nonmodification of the internal structure of the Andiroba leaf suggests to us that although under adverse conditions (in the Amazon rainforest), the photosynthesis process was not affected over time because all cellular structures of the leaf are preserved. Perhaps this is why this species is not considered threatened and did not need to develop survival mechanisms outside of this ecosystem. However, the substantial logging in this region can affect the development of this plant in the long term.

\subsection{AFM Analysis \\ 3.2.1. Morphology Analysis}

AFM technique has become an important tool for analyzing biological systems, including plant leaves, e.g., [18-20,44,66,67], due to its high sensitivity and the possibility of identifying structures on a micro or nanometric scale [68]. The AFM topographical maps showed in Figure 4 present 2D and 3D representations of the leaf side whose the stomata are observed (abaxial) with three different sizes, such as $50 \times 50 \mu \mathrm{m}$ (Figure 4a,d), $20 \times 20 \mu \mathrm{m}$ (Figure $4 \mathrm{~b}, \mathrm{e})$, and $10 \times 10 \mu \mathrm{m}$ (Figure $4 \mathrm{c}, \mathrm{f}$ ), respectively. Such different sizes were obtained so that the topographical parameters could be studied according to their scale dependence. 
Three pores were observed on the $50 \times 50 \mu \mathrm{m}$ image, one on the $20 \times 20 \mu \mathrm{m}$, and none in the $10 \times 10 \mu \mathrm{m}$. The average pore diameter size was calculated using the image with three pores, presenting a value of $7.423 \pm 0.281 \mu \mathrm{m}$. The pore morphology was very similar to that described for Anacardium occidentale L. leaves [18,19,53], where the ostiole and a pair of guardians cells are observed.
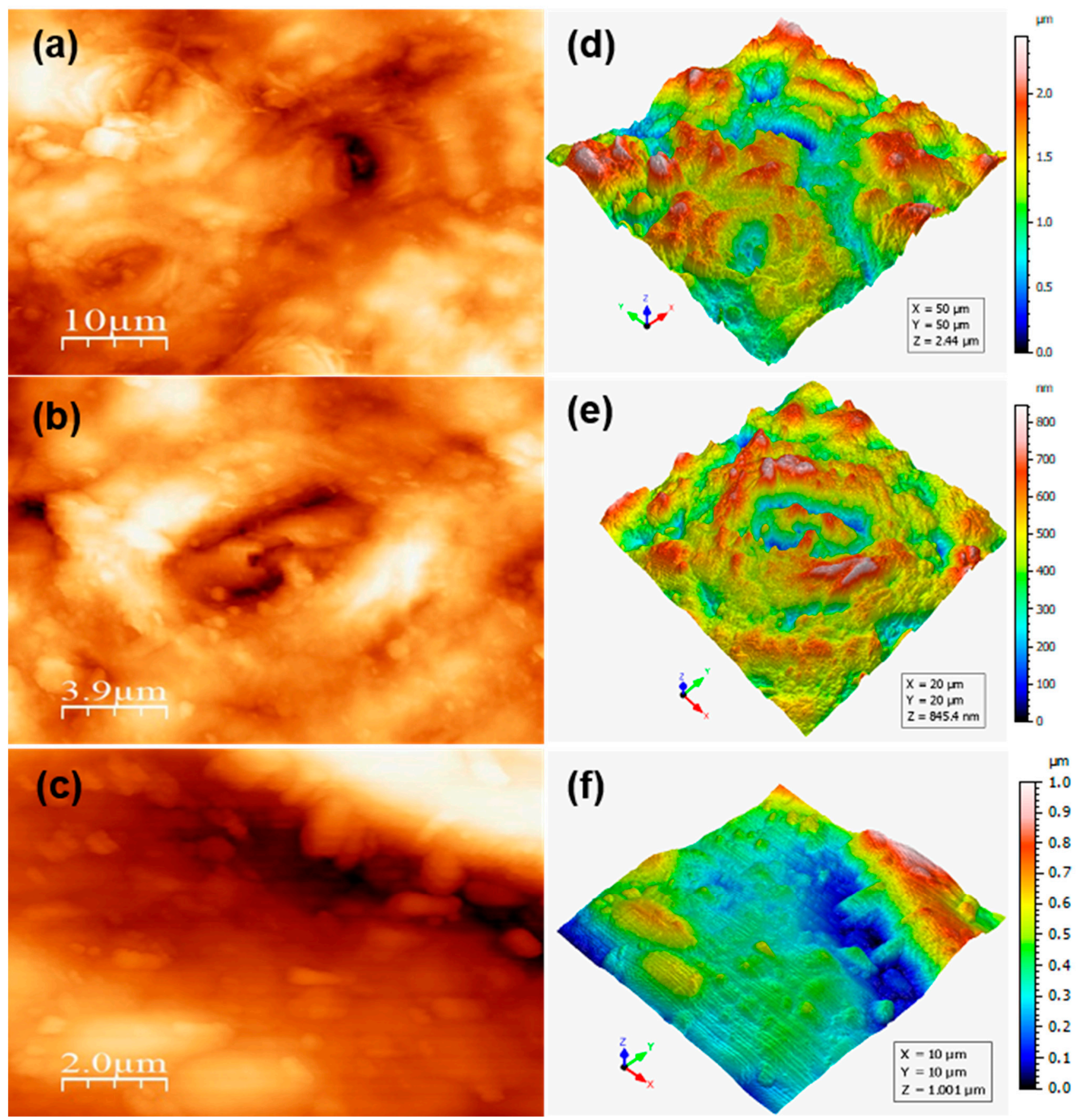

Figure 4. AFM topographical maps of Andiroba leaf surface of the abaxial side, highlighting 2D (a-c) and 3D (d-f) representations for maps with the size of $50 \times 50 \mu \mathrm{m}, 20 \times 20 \mu \mathrm{m}$, and $10 \times 10 \mu \mathrm{m}$, respectively.

The smallest image Figure 4c shows a large hole that represents a region within a pore, close to a narrow hole. In Figure 4f, this hole is highlighted by bulky depressions containing more valleys than rough peaks. Figure $4 \mathrm{~d}$ does not highlight the outline of the three pores seen in Figure 4a. However, these images reveal how the morphology is 
different depending on the size and the region observed. Moreover, it is possible to see epidermal streaks on the lateral portion of the stoma, with orientation parallel to guardian cells, like in [69], whose paracytic stoma was also observed by [70] be seen Figure 4e.

This difference can be better understood when the discrepancies in the data regarding the surface statistical parameters are analyzed, whose values are shown in Table 1. The surface roughness changed according to the evaluated area size, which is observed for both average roughness $\left(R_{a}\right)$ and root mean square roughness $\left(R_{R M S}\right)$. Variance analysis of roughness parameters shows a significant difference between the means $(p<0.05)$, where the Tukey test reveals that only S10 is different from S50 and S20. The S50 area shows the highest roughness, while the smallest was seen for S10. It is important to mention that the region with the lowest evaluated area, S10, still had less roughness than the area with the highlighted pore S20 $(0.237$ against $0.34 \mu \mathrm{m})$. In fact, the pore hole S20 is visually deeper than that of the S10 image. The greater roughness in this region can promote greater water mobility, which is also in accordance with the greater contact angle found for the abaxial side, as more hydrophobic surfaces have greater water mobility.

Table 1. Surface height parameters $R_{a}, R_{R M S}, S_{S}$, and Ks. The average results were expressed as mean values and standard deviation.

\begin{tabular}{ccccc}
\hline Parameters & Units & S50 & S20 & S10 \\
\hline $\mathrm{R}_{\mathrm{a}}$ & $\mu \mathrm{m}$ & $0.571 \pm 0.065$ & $0.34 \pm 0.027$ & $0.237 \pm 0.015$ \\
\hline $\mathrm{R}_{\mathrm{RMS}}$ & $\mu \mathrm{m}$ & $0.700 \pm 0.081$ & $0.413 \pm 0.033$ & $0.296 \pm 0.018$ \\
\hline $\mathrm{S}_{\mathrm{S}}$ & - & $0.136 \pm 0.073$ & $-0.424 \pm 0.005$ & $0.851 \pm 0.014$ \\
\hline $\mathrm{K}_{\mathrm{s}}$ & - & $2.582 \pm 0.045$ & $2.853 \pm 0.018$ & $3.061 \pm 0.067$ \\
\hline
\end{tabular}

Surface asymmetry-skewness (Ss) and shape of the height distribution-kurtosis (Ks) also differentiate the areas with different sizes, where also is observed significant difference $(p<0.05)$ and still all sizes are different between themselves according to Tukey test. In the larger (S50) and smaller (S10) area, Ss is positive, while the intermediate area (S20) is negative, revealing that this area has its height distribution tilted to the left. The most symmetrical area is designated to be S50, as Ss is close to 0, suggesting that the distribution of rough peaks is more symmetrical for larger regions. Furthermore, Ks was smaller than 3 for S50 and S20, showing that the distribution of rough peaks is more flattened for large regions. In contrast, smaller regions (S10) $(\mathrm{Ks} \sim 3)$ have a Gaussian-like distribution (platykurtic behavior), which is confirmed by representations of the relative frequencies of the height distribution exhibited in Figure S1, explicitly, in Figure S1a-c.

\subsubsection{Advanced Analysis of ISO and Morphological Parameters}

The remarkable differences in spatial patterns as a function of scale size can also be observed by the evolution of some other non-functional ISO and morphological statistical parameters. The graphical representations of these parameters are shown in Figure S1, where their detailed physical definitions can be found in refs. [71-73]. The ISO Sk parameter (Figure S1d-f) reveals a decrease of the core roughness from S50 to S10 due to the decrease in global height roughness ( $R a$ and RRMS). The same phenomenon was seen for reduced peak height (Spk), but for reduced valley depth (Svk), an increase is observed, attributed to a more platykurtic surface for smaller areas. Moreover, due to the decrease in global roughness, the reduced peaks (Smr1) were more abundant for S10, although the lowest value was found for S20. In contrast, the greater abundance of reduced valleys (Smr2) occurred for S50, decreasing to S10. Additionally, the behavior of the volume parameters (Figure S1g-i) reveals the different settings for the distribution of material portions in the core. As shown in Table 2, the highest volume of material at the peaks (Vmp) was observed for S50 and the lowest for S10. This was expected because of the highly rough profile of S50 compared to S10. However, the largest void volume in the valleys (Vvv) was recorded for S20 and the lowest for S10. Probably, the deep valleys between the guardian cells explain 
this phenomenon. Moreover, it is observed that both the volume of material (Vmc) and the empty volume (Vvc) of the central part of the images decrease fromS50 to S10, as an effect of the change in roughness.

Table 2. ISO and morphological parameters of Andiroba leaf surface for three different size image.

\begin{tabular}{ccccc}
\hline Sk Parameters & Units & S50 & S20 & S10 \\
\hline Sk & $\mu \mathrm{m}$ & 0.4003 & 0.3475 & 0.03477 \\
\hline Spk & $\mu \mathrm{m}$ & 0.1839 & 0.09454 & 0.02651 \\
Svk & $\mu \mathrm{m}$ & 0.2105 & 0.23 & 0.02454 \\
Smr1 & $\%$ & 11.19 & 8.992 & 13 \\
\hline Smr2 & $\%$ & 89.30 & 87.48 & 81.91 \\
\hline Volume Parameters & - & S50 & S20 & S10 \\
\hline Vmp & $\mu \mathrm{m}^{3} / \mu \mathrm{m}^{2}$ & 0.009091 & 0.004902 & 0.001329 \\
\hline Vmc & $\mu \mathrm{m}^{3} / \mu \mathrm{m}^{2}$ & 0.1443 & 0.1272 & 0.01356 \\
\hline Vvc & $\mu \mathrm{m}^{3} / \mu \mathrm{m}^{2}$ & 0.1996 & 0.1613 & 0.01977 \\
\hline Vvv & $\mu \mathrm{m}^{3} / \mu \mathrm{m}^{2}$ & 0.02133 & 0.02275 & 0.002437 \\
\hline Particle Parameters & - & $\mathrm{S} 50$ & $\mathrm{~S} 20$ & $\mathrm{~S} 10$ \\
\hline Particle count & - & 1038 & 241 & 50 \\
\hline Covering & $\%$ & 53.73 & 49.88 & 49.77 \\
\hline Density & Particles $/ \mathrm{mm}^{2}$ & $10,335,877$ & 128,538 & 96,400 \\
\hline
\end{tabular}

Regarding the surface coverage (Figure S1j-m), larger particle distributions are computed in large areas, as the MountainsMap segmentation algorithm found only 50 particles for S10, a much lower value than for the others, which we attribute to the smaller area size. The surface coverage was higher in S50 and intermediate in S20, confirming the effect of the area size on the particle distribution. Moreover, the highest density was also observed for S50, and the lowest occurred for S10. These particles indicate cells or clusters of cells on the surface, e.g., guardian cells with their particular function in the plant's working mechanism.

\subsubsection{Surface Microtexture Evaluation}

The use of qualitative renderings images to understand the microtexture of surfaces has been extensively employed, e.g., [40,74]. The microtexture of the leaf was studied using qualitative renderings based on the coding of the height map of the image by different height levels with different colors [40]. Figure 5a-c show renderings of the ridges created by the directions of the valleys and peaks. The darkest blue regions are deep valley regions, while the deepest red regions represent the valley directions. In Figure 6a, the stomata form together with the common epidermal cells agglomerate of furrows, revealing that the deepest valleys are around those cells, explaining a higher roughness value for the $50 \times 50 \mu \mathrm{m}$ image. The organization of the cells in Figure $5 \mathrm{~b}$ reveals a deep valley between the guardian cells. It is also worth noting that the geometry of these furrows is organized as a whirlpool, directing the path into the hole. In the smaller image Figure $5 c$, we can see a more planar structure without significant differences between peaks and valleys.

The following renderings (Figure $5 \mathrm{~d}-\mathrm{f}$ ) show contour lines around particles, wherein Figure 5e, the region where the largest hole was observed, is wholly flooded while the region where the guardian cells remained intact. Along the yellow contour lines, the fluid path leads to the bottom of the pore. Similar behavior can also be seen in Figure 5d. In the more planar image Figure 5f, the contour lines indicate more submerged regions. This fluid probably flows to the regions whose valleys are more prevalent, in other words, the pores. The regions between the pores Figure $5 \mathrm{a}, \mathrm{d}$ appear to have more valleys. The highest maximum depth of furrow occurred for this image $(0.8207 \mu \mathrm{m})$, which was confirmed for 
the mean depth $(0.3016 \mu \mathrm{m})$, as shown in Table 3 . However, the highest furrows density was noted for $\mathrm{S} 10\left(44,170 \mathrm{~cm} / \mathrm{cm}^{2}\right)$, indicating a flatness and ordering of cells in the regions outside the pore. The fact that the image with the pore has a maximum depth furrow less than that of the largest image was noteworthy. We attribute this behavior to the high elevation that the guardian cells create around the pore, leaving larger valleys between the pores, through which water also drains out of the plant.

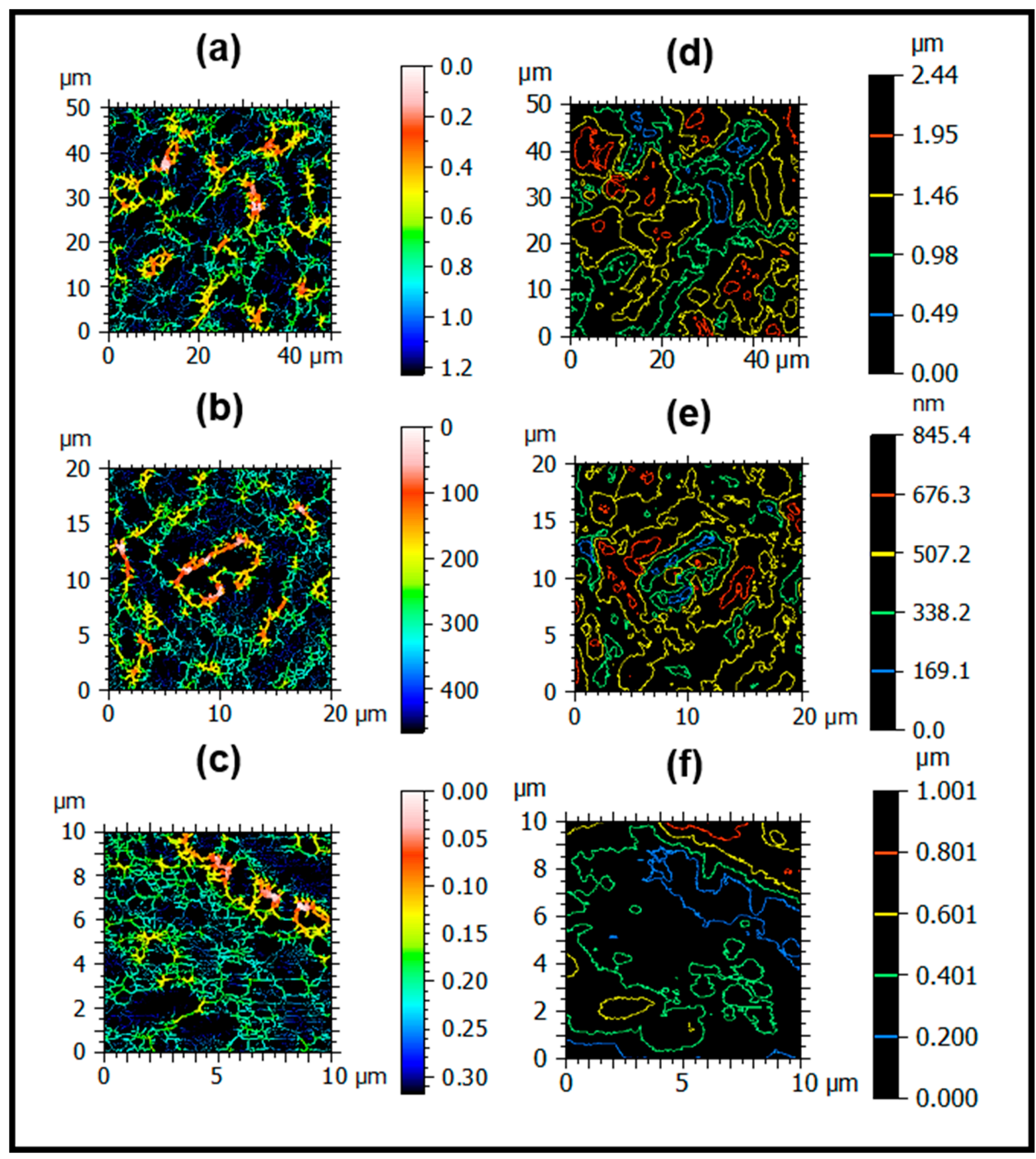

Figure 5. Graphical representations of the furrows $(\mathbf{a}-\mathbf{c})$ and contour lines $(\mathbf{d}-\mathbf{f})$ of S50, S20, and S10, respectively. 


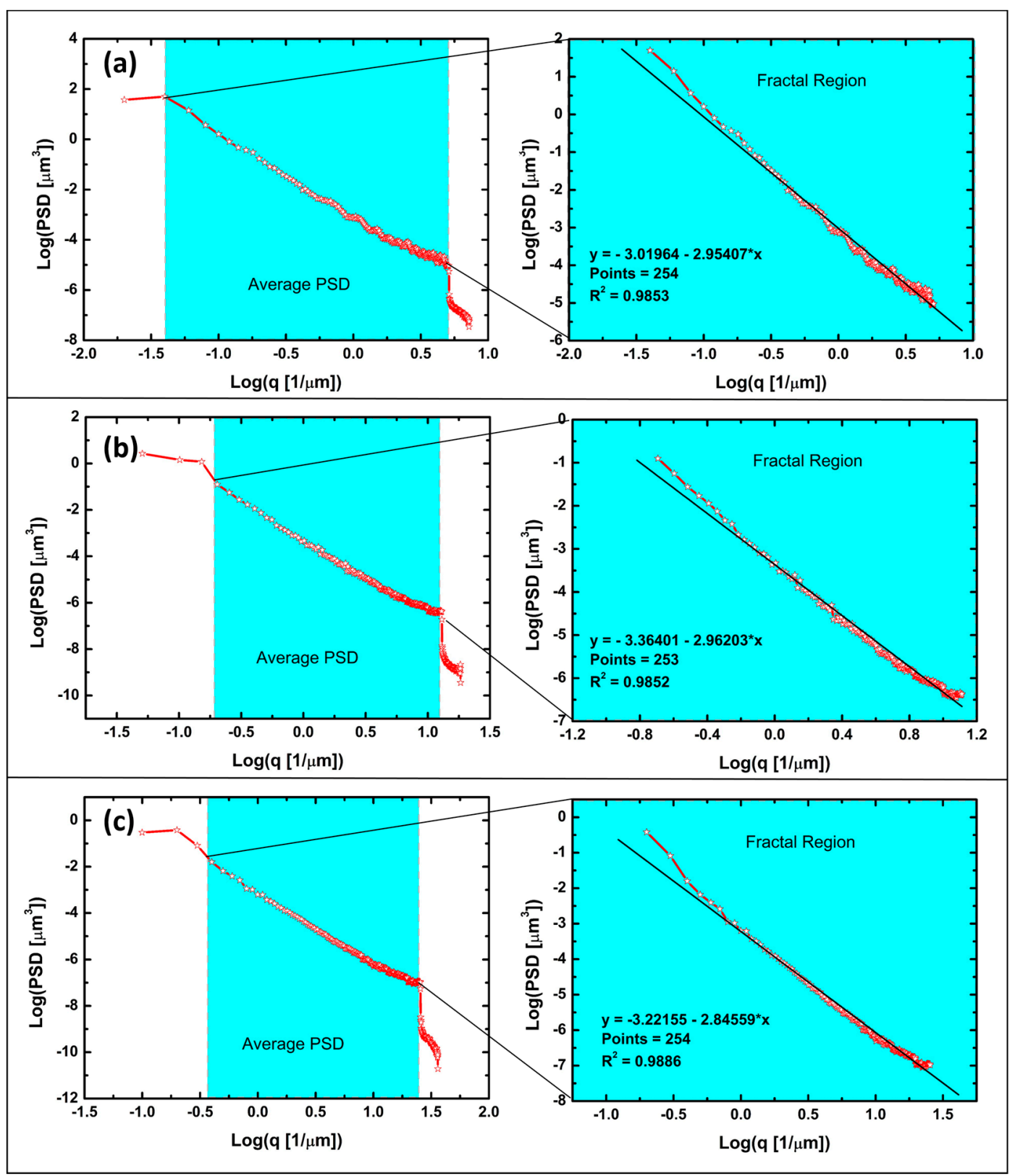

Figure 6. Power spectral density (PSD) and linear fit for the fractal region of the spectrum exposed by AFM topographical maps of the abaxial side for $(\mathbf{a}, \mathbf{b})$ S50, (c,d) S20, and (e,f) S10.

On the other hand, the texture directions (Figure S2) values of the three image sizes reveal that the texture isotropy has a random behavior according to the image size (Table 3). The first texture direction showed very low angles for both the largest S50 and intermediate S10 areas. Although real surfaces generally exhibit a strongly anisotropic surface, e.g., wood [75], Andiroba leaf exhibits surface texture that varies with the area size evaluated, but no relevant differences can be observed here, besides the values being similar and close to $50 \%$, representing a surface that is neither too isotropic nor anisotropic. The geometry of isotropic surfaces does not change as a function of texture direction [76], but the leaf (a real surface) showed different directions for the three sizes (Table 3). We can attribute this fact to the great difference in the profile of the cells found in the specific areas studied, which did not necessarily affect the isotropy significantly. 
Table 3. Furrows and texture parameters of Andiroba leaf abaxial side.

\begin{tabular}{ccccc}
\hline Furrow Parameter & Unit & S50 & S20 & S10 \\
\hline Max. depth & $\mu \mathrm{m}$ & 0.8207 & 0.6314 & 0.1169 \\
\hline Mean depth & $\mu \mathrm{m}$ & 0.3016 & 0.1771 & 0.03247 \\
\hline Mean density & $\mathrm{cm} / \mathrm{cm}^{2}$ & 0.2105 & 16,011 & 44,170 \\
\hline Texture Parameter & Unit & S50 & S20 & S10 \\
\hline Texture Isotropy & $\%$ & 60.72 & 49.54 & 55.38 \\
\hline First Dir. & $\circ$ & 0.02569 & 180 & 0.01696 \\
\hline Second Dir. & $\circ$ & 90.01 & 44.96 & 161.5 \\
\hline Third Dir. & $\circ$ & 33.78 & 135 & 168 \\
\hline
\end{tabular}

\subsubsection{Fractal Analysis of Leaf Surface}

The analysis of fractal objects in nature has its importance for describing their unique spatial patterns and started with the excellent work of Mandelbrot [77]. Such description can be made using several branches of fractal theory, e.g., power spectrum density (PSD), fractal dimension (FD), fractal lacunarity (FL), and fractal succolarity (FS), as we report in this approach. The power spectrum density of the leaf abaxial side images with different sizes is displayed in Figure 6. Figure 6a-c shows the Average PSD of the leaf abaxial surface of S50, S20, and S10 (S50), where we highlight the fractal region chosen to estimate the Hurst coefficient $(\mathrm{H})$ as a useful quantitative parameter in the analysis of the dominant spatial frequencies displayed by the surface as a function of the scale.

The PSD decomposes the surface into contributions of different spatial frequencies (wave vectors) using the Fourier transform of the height distribution function. According to Jacobs et al. [33], PSD is invariant concerning the size of the image and the number of pixels of the same. However, the enlargement of the image in the region of the stomata of the leaf can provide details of its internal topography. Thus, to confirm whether one of the enlargements reveals internal characteristics of the stomata, the Hurst coefficient $(\mathrm{H})$ values were computed and are shown in Table 4. S50 and S20 show higher H values than S10. The variance analysis shows a significant global difference between samples, but Tukey test reveals that only S10 differs from S50 and S20 $(p<0.05)$. A lower H indicates a higher contribution from higher frequencies, creating a larger space-filling profile when compared to a higher $\mathrm{H}$ value. Therefore, the results suggest that the internal topographic profile of the stomata presents a greater contribution of higher frequencies, with greater spacefilling, about the external part. However, the stomata's internal and external topographic difference from the S10 image is still barely noticeable visually, as the difference in $\mathrm{H}$ between S10 and the other images (S50 and S20) is very small. However, this difference suggests that even greater scale size may reveal singular characteristics of the internal region of the stomata. Jacobs et al. [33] emphasize that two surfaces can have the same Sa value, the same phase, and be isotropic, but with a different $\mathrm{H}$ value, which establishes completely different roughness patterns.

The fractal geometry has been used to study the spatial complexity of leaves on micro and nanometric scale, e.g., $[19,20]$. The FD decreases S50 to S10, revealing a decrease of the spatial complexity (topographical irregularities) as a function of scale size. In this regard, the variance analysis shows a significant difference between the means $(p<0.05)$, but Tukey test reveals that S10 and S20 are different from S50. Thus, it is possible to conclude that the surface microtexture changes according to the scale size, following a decrease in the roughness behavior. Furthermore, FL (Figure S3) confirms that scale size influences surface microtexture because the lowest $\beta$ coefficients, estimated by linear fits on the lacunarity distribution, are obtained for S50 and S20 and the largest for S10 (Table 4). According to Matos et al. [78], when $\beta$ is lower, the surface has a microtexture more homogeneous, while the highest values are related to surface microtextures more heterogeneous. Thus, 
comparatively, S10 has its surface microtexture more heterogeneous than S50 and S20 that exposed similar $\beta$ coefficients values.

Table 4. Fractal parameters of leaf surface abaxial side as a function of the scale size. The average results were expressed as mean values and standard deviation.

\begin{tabular}{ccccc}
\hline Parameters & Unit & S50 & S20 & S10 \\
\hline H & - & $0.4894 \pm 0.010$ & $0.4881 \pm 0.005$ & $0.4169 \pm 0.008$ \\
\hline FD & - & $2.183 \pm 0.012$ & $2.129 \pm 0.008$ & $2.114 \pm 0.005$ \\
\hline FS & - & $0.474 \pm 0.030$ & $0.254 \pm 0.008$ & $0.363 \pm 0.012$ \\
\hline I $\beta$ | & - & $0.029 \pm 0.002$ & $0.024 \pm 0.001$ & $0.056 \pm 0.009$ \\
\hline E & - & $0.998 \pm 0.002$ & $0.998 \pm 0.001$ & $0.996 \pm 0.005$ \\
\hline$f_{\text {out }}$ & - & $0.001 \pm 0.001$ & $0.001 \pm 0.001$ & $0.003 \pm 0.004$ \\
\hline
\end{tabular}

Furthermore, fractal succolarity, which relates topographical lower and upper bands, confirmed that stomata are regions of greater fluid penetration, which reveals yet another unique characteristic of the different patterns of the leaf microtexture as a function of the scale size. The lowest succolarity was registered for S20 and the highest for S50 (Table 4), exhibiting a significant global difference $(p<0.05)$, where the Tukey test reveals that S20 and S10 are statistically different from S50. When succolarity (surface percolation) is equal to 0.5 , the surface has ideal percolation, but the surface percolation is lower if the value is less than 0.5. In this way, we can conclude that $\mathrm{S} 20$ absorbs and retains less water than larger and smaller areas outside the stomata due to its lower fractal succolarity. Notably, it is clear that leaf surface spatial patterns change according to scale size, suggesting that these physical and mathematical tools can be applied to investigate topographical differences in plant species whose anatomies are similar.

Finally, we employ a toolkit from statistics and information theory to characterize the degree of uniformity of the asperities over the spatial domains of the leaf surface, using surface entropy and outlier fraction quantitative parameters. Table 4 unveils that all images presented very high values for the topographic entropy $(\mathrm{E} \sim 1)$ and very low values for the outlier fraction $\left(f_{\text {out }}<<1\right)$ in the local distribution LRMS $(x, y)$, where both do not present significant differences between sizes $(p>0.05)$. Both results provide evidence that the surface roughness displays a high uniformity at the global and neighborhood-based scale, despite the previously detected differences in the fractal properties. This means that the leaf surfaces have asperities that are hierarchically arranged to promote robustness in uniformity and variations in spatial complexity. Moreover, when scanning the topography with moving windows, it is unlikely to find sudden spatial variations in the roughness.

\subsection{Wettability Analysis}

The contact angles of Andiroba for the abaxial and adaxial sides are displayed in Figure 7. The adaxial side exhibited the smallest angle, while the abaxial side was more prominent, as shown in Table 5. This was observed for both the shortest and largest time, showing that the abaxial side is more hydrophobic. However, in general, as the contact angle was less than $90^{\circ}$, the leaf has a hydrophilic behavior. Previous studies have concluded that the abaxial side of the leaves is more hydrophobic than the adaxial side, e.g., $[79,80]$. Probably, the epicular wax film (usually formed by nonpolar lipid groups) is thicker on the abaxial side, promoting greater hydrophobicity. In addition, due to the plant's recurrent location, this face is more likely to receive water droplets, which justifies the evolutionary mechanism of additional protection [81]. 
(a)

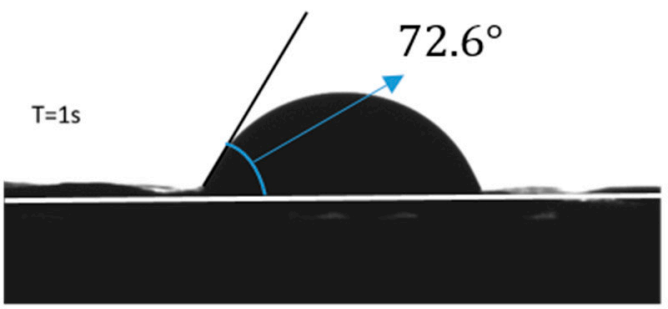

(c)

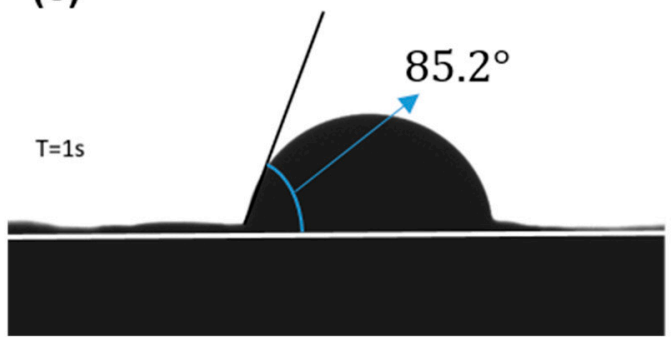

(b)

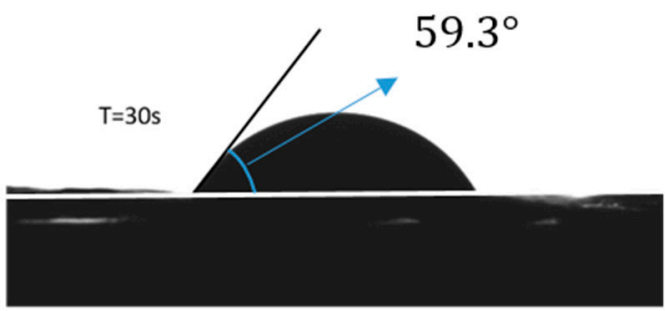

(d)

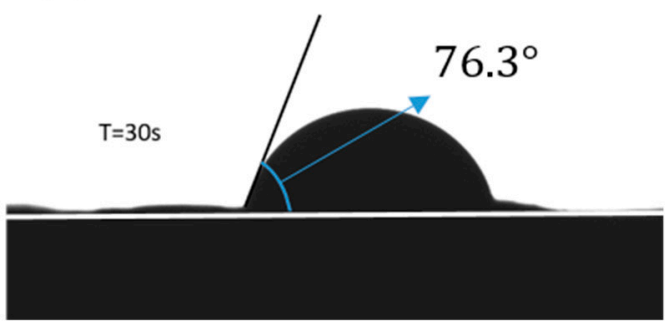

Figure 7. Contact angle for both sides of the leaf. (a) $\mathrm{T}=1 \mathrm{~s}$ and $(\mathbf{b}) \mathrm{T}=30 \mathrm{~s}$ for adaxial, and (c) $\mathrm{T}=1 \mathrm{~s}$ and $(\mathbf{d}) \mathrm{T}=30 \mathrm{~s}$ for abaxial.

Table 5. Contact angle and surface energy measurements for both sides of the leaf.

\begin{tabular}{|c|c|c|c|}
\hline Parameters & Units & Adaxial & Abaxial \\
\hline Angle $(\mathrm{T}=1 \mathrm{~s})$ & o & 72.6 & 85.2 \\
\hline Angle $(\mathrm{T}=30 \mathrm{~s})$ & o & 59.3 & 76.3 \\
\hline Mean angle & o & $67.49 \pm 4.8$ & $80.05 \pm 2.6$ \\
\hline Surface energy & UE.cm ${ }^{-2}$ & - & $35.44 \pm 0.3$ \\
\hline $\mathrm{R}_{\mathrm{f}}$ & - & - & $1.054 \pm 0.002$ \\
\hline
\end{tabular}

On the abaxial side, the low roughness factor, $\mathrm{Rf}=1.05$, also explains the hydrophilic behavior of this leaf. When $R_{f}$ is $\leq 1$, the leaf has a flatter surface and, therefore, more hydrophilic [82]. More hydrophobic leaves have much higher roughness factor, e.g., $R_{\mathrm{f}}=1.69$ Thalia geniculata [81], $\mathrm{R}_{\mathrm{f}}=1.55$ Nelumbo nucifera [50], and $\mathrm{R}_{\mathrm{f}}=1.42$ Colocasia esculenta [82]. In addition, the high surface energy for this side is in accordance with the hydrophilic behavior and the low roughness factor shown. This suggests that the contact angle is also influenced by the surface terminations found on the leaf surface [83] because different topographical profiles modify the rough peak structures by changing the surface dynamics. Therefore, the unique surface architecture of the adaxial side of the leaf is designed to have greater wettability than the abaxial side, although both sides have shown hydrophilicity.

In this paper, we successfully map the morphology, wettability, and fractal behavior of the topographic spatial patterns of the Amazon Andiroba leaf, using microscopy and fractal theory. The SEM images revealed differences in the morphology of the abaxial and adaxial sides of the leaf, where cells specialized in the gases exchange with the environment were only observed on the abaxial side. The internal structure of the leaf presented the cells expected for the architecture of this species. Notably, however, striated tissues were only observed on the adaxial side, which also exhibited a more hydrophilic surface than the abaxial side. The micromorphology evaluation of the abaxial side surface revealed singularities of the spatial patterns as a function of the scale size of the obtained AFM topographical images. The topographic roughness decreased when the scale decreases, and the skewness and kurtosis exhibit different patterns, mainly for the intermediate studied scale size. A similar observation of this behavior was observed by the advanced ISO parameters 
and other parameters related to the microtexture of the leaf. The power spectrum density, fractal, and surface entropy parameters confirmed the strong fractal behavior of the plant leaf architecture, where the largest scale size displays greater irregularity, low dominant spatial frequencies, greater succolarity, high relative homogeneity, and good topographical uniformity. The pattern of decreasing topographic roughness and the persistent fractal behavior suggest that Andiroba leaf architecture can be easily monitored using microscopy techniques associated with fractal theory mathematical tools.

Supplementary Materials: The following are available online at https: / www.mdpi.com/article / 10.3390/app11135848/s1, Figure S1: More relevant results of statistical and functional parameters, presenting of S1(a) to S1(c) height distribution histograms, S1(d) to S1(f) Sk parameters, S1(g) to S1(i) volume parameters, and S1(j) to S1(m) volume parameters for S50, S20, and S10, respectively, Figure S2: Representation of the surface texture directions of the more relevant analyzed samples for (a) S50, (b) S20, and (c) S10, Figure S3: Lacunarity distribution of AFM topographic maps with sizes of (a) $50 \times 50 \mu \mathrm{m}$ (S50), (b) $20 \times 20 \mu \mathrm{m}$ (S20), and (c) $10 \times 10 \mu \mathrm{m}$ (S10).

Author Contributions: R.S.M.: conceptualization, data curation, investigation, methodology, and writing-original draft. Ş.Ţ.: funding acquisition, and writing-original draft. G.V.S.M.: formal analysis, resources, and writing - review and editing. E.P.P.: formal analysis, methodology, software, and writing-review and editing. M.A.P.: formal analysis, methodology, software, and writingreview and editing. L.G.A.: methodology and writing - review and editing. N.S.F.: conceptualization, project administration, validation, visualization, conceptualization, and writing-original draft. All authors have read and agreed to the published version of the manuscript.

Funding: This research was supported by the Brazilian funding agency Conselho Nacional de Desenvolvimento Científico e Tecnológico-CNPq (grant no. 309054/2019-2).

Institutional Review Board Statement: Not applicable.

Informed Consent Statement: Not applicable.

Data Availability Statement: The data presented in this study are available on request from the corresponding author. The data are not publicly available due to large amount of data.

Acknowledgments: There are no acknowledgments.

Conflicts of Interest: The authors declare no conflict of interest. The funders had no role in the design of the study; in the collection, analyses, or interpretation of data; in the writing of the manuscript, or in the decision to publish the results.

\section{References}

1. Grande, C.; Tradicional, M.; Medicinais, P.; Medicinais, A. Socio-Economic Aspects of Medicinal Plants and Animal Trading in Metropolitan Area of North and Northeastern Brazil. Rev. Biol. Ciênc.Terra 2008, 8, 181-189.

2. Semirian, C.A.; Isolde, D.K.F. Seed quality evaluation by tetrazolium staining during a desiccation study of the recalcitrant seeds of Carapa guianensis Aubl. and Carapa surinamensis Miq.-Meliaceae. Afr. J. Agric. Res. 2017, 12, 1005-1013. [CrossRef]

3. Dos Santos, B.M.; Rosito, J.M. Uso de plantas medicinais como instrumento de conscientização: Responsabilidade social e ambiental. Rev. Monogr. Ambient. 2012, 7. [CrossRef]

4. Londres, M.; Schulze, M.; Staudhammer, C.L.; Kainer, K.A. Population Structure and Fruit Production of Carapa guianensis (Andiroba) in Amazonian Floodplain Forests. Trop. Conserv. Sci. 2017, 10. [CrossRef]

5. Wanzeler, A.M.V.; Júnior, S.M.A.; Gomes, J.T.; Gouveia, E.H.H.; Henriques, H.Y.B.; Chaves, R.H.; Soares, B.M.; Salgado, H.L.C.; Santos, A.S.; Tuji, F.M. Therapeutic effect of andiroba oil (Carapa guianensis Aubl.) against oral mucositis: An experimental study in golden Syrian hamsters. Clin. Oral Investig. 2017, 22, 2069-2079. [CrossRef] [PubMed]

6. De Barros, F.N.; Farias, M.P.O.; Tavares, J.P.C.; Alves, L.C.; Faustino, M.A.D.G. In vitro efficacy of oil from the seed of Carapa guianensis (andiroba) in the control of Felicola subrostratus. Rev. Bras. Farm. 2012, 22, 1130-1133. [CrossRef]

7. Farias, M.; Teixeira, W.; Wanderley, A.; Alves, L.; Faustino, M. Avaliação in vitro dos efeitos do óleo da semente de Carapa guianensis Aubl. sobre larvas de nematóides gastrintestinais de caprinos e ovinos. Rev. Bras. Plantas Med. 2010, 12, 220-226. [CrossRef]

8. Meccia, G.; Quintero, P.; Rojas, L.B.; Usubillaga, A.; Velasco, J.; Diaz, T.; Diaz, C.; Velásquez, J.; Toro, M. Chemical Composition of the Essential Oil from the Leaves of Carapa guianensis Collected from Venezuelan Guayana and the Antimicrobial Activity of the Oil and Crude Extracts. Nat. Prod. Commun. 2013, 8, 1641-1642. [CrossRef] 
9. Goodman, R.C.; Aramburu, M.H.; Gopalakrishna, T.; Putz, F.E.; Gutiérrez, N.; Alvarez, J.L.M.; Aguilar-Amuchastegui, N.; Ellis, P.W. Carbon emissions and potential emissions reductions from low-intensity selective logging in southwestern Amazonia. For. Ecol. Manag. 2019, 439, 18-27. [CrossRef]

10. Burlando, B.; Cornara, L. Revisiting Amazonian Plants for Skin Care and Disease. Cosmetics 2017, 4, 25. [CrossRef]

11. Da Cunha, A.C.; Mustin, K.; Dos Santos, E.S.; Dos Santos, É.W.G.; Guedes, M.C.; Cunha, H.F.A.; Rosman, P.C.C.; Sternberg, L.D.S.L. Hydrodynamics and seed dispersal in the lower Amazon. Freshw. Biol. 2017, 62, 1721-1729. [CrossRef]

12. Strieder, M.L.; Da Silva, P.R.F.; Rambo, L.; Bergamaschi, H.; Dalmago, G.A.; Endrigo, P.C.; Jandrey, D.B. Características de dossel e rendimento de milho em diferentes espaçamentos e sistemas de manejo. Pesqui. Agropecu. Bras. 2008, 43, 309-317. [CrossRef]

13. Hacke, U. Functional and Ecological Xylem Anatomy. Funct. Ecol. Xylem Anat. 2015, 1-281. [CrossRef]

14. Cope, J.S.; Corney, D.; Clark, J.Y.; Remagnino, P.; Wilkin, P. Plant species identification using digital morphometrics: A review. Expert Syst. Appl. 2012, 39, 7562-7573. [CrossRef]

15. Wang, F.; Li, S.; Wang, L. Fabrication of artificial super-hydrophobic lotus-leaf-like bamboo surfaces through soft lithography. Colloids Surf. A Physicochem. Eng. Asp. 2017, 513, 389-395. [CrossRef]

16. Liu, P.; Gao, Y.; Wang, F.; Yang, J.; Yu, X.; Zhang, W.; Yang, L. Superhydrophobic and self-cleaning behavior of Portland cement with lotus-leaf-like microstructure. J. Clean. Prod. 2017, 156, 775-785. [CrossRef]

17. Gray-Munro, J.; Campbell, J. Mimicking the hierarchical surface topography and superhydrophobicity of the lotus leaf on magnesium alloy AZ31. Mater. Lett. 2017, 189, 271-274. [CrossRef]

18. Ramos, G.Q.; Da Costa, Í.C.; Da Costa, M.E.H.M.; Pinto, E.P.; Matos, R.S.; Da Fonseca Filho, H.D. Stereometric analysis of Amazon rainforest Anacardium occidentale L. leaves. Planta 2021, 253, 1-9. [CrossRef] [PubMed]

19. Ramos, G.Q.; Matos, R.S.; Da Fonseca Filho, H.D. Advanced Microtexture Study of Anacardium occidentale L. Leaf Surface From the Amazon by Fractal Theory. Microsc. Microanal. 2020, 26, 989-996. [CrossRef] [PubMed]

20. Salcedo, M.O.C.; Zamora, R.R.M.; Carvalho, J.C.T. Study Fractal Leaf Surface of the Plant Species Copaifera Sp. Using the Microscope Atomic-Force-AFM. Rev. ECIPerú 2016, 13, 10-16. [CrossRef]

21. Țălu, Ş.; Bramowicz, M.; Kulesza, S.; Dalouji, V.; Solaymani, S.; Valedbagi, S. Fractal features of carbon-nickel composite thin films. Microsc. Res. Tech. 2016, 79, 1208-1213. [CrossRef]

22. Arman, A.; Ţălu, S..; Luna, C.; Ahmadpourian, A.; Naseri, M.; Molamohammadi, M. Micromorphology characterization of copper thin films by AFM and fractal analysis. J. Mater. Sci. Mater. Electron. 2015, 26, 9630-9639. [CrossRef]

23. Țălu, S..; Stach, S.; Abdolghaderi, S. The effects of deposition time on the nanoscale patterns of Ag/DLC nanocomposite synthesized by RF-PECVD. Microsc. Res. Tech. 2019, 82, 572-579. [CrossRef]

24. Ţălu, Ş.; Stach, S.; Valedbagi, S.; Bavadi, R.; Elahi, S.M.; Ţălu, M. Multifractal characteristics of titanium nitride thin films. Mater. Sci. 2015, 33, 541-548. [CrossRef]

25. Țălu, Ş.; Stach, S.; Méndez, A.; Trejo, G.; Țălu, M. Multifractal Characterization of Nanostructure Surfaces of Electrodeposited Ni-P Coatings. J. Electrochem. Soc. 2013, 161, D44-D47. [CrossRef]

26. Gong, Y.; Misture, S.T.; Gao, P.; Mellott, N.P. Surface Roughness Measurements Using Power Spectrum Density Analysis with Enhanced Spatial Correlation Length. J. Phys. Chem. C 2016, 120, 22358-22364. [CrossRef]

27. Țălu, Ş.; Stach, S.; Sueiras, V.; Ziebarth, N.M. Fractal Analysis of AFM Images of the Surface of Bowman's Membrane of the Human Cornea. Ann. Biomed. Eng. 2014, 43, 906-916. [CrossRef]

28. Stach, S.; Dallaeva, D.; Ţălu, Ş.; Kaspar, P.; Tománek, P.; Giovanzana, S.; Grmela, L. Morphological features in aluminum nitride epilayers prepared by magnetron sputtering. Mater. Sci. 2015, 33, 175-184. [CrossRef]

29. Stach, S.; Sapota, W.; Ţălu, Ş.; Ahmadpourian, A.; Luna, C.; Ghobadi, N.; Arman, A.; Ganji, M. 3-D surface stereometry studies of sputtered TiN thin films obtained at different substrate temperatures. J. Mater. Sci. Mater. Electron. 2017, 28, 2113-2122. [CrossRef]

30. Bobrovskij, I.N. How to Select the most Relevant Roughness Parameters of a Surface: Methodology Research Strategy. IOP Conf. Ser. Mater. Sci. Eng. 2018, 302, 12066. [CrossRef]

31. Horcas, I.; Fernández, R.; Rodriguez, J.M.G.; Colchero, J.; Gomez-Herrero, J.; Baro, A.M. WSXM: A software for scanning probe microscopy and a tool for nanotechnology. Rev. Sci. Instrum. 2007, 78, 013705. [CrossRef] [PubMed]

32. Digital Surf. MountainsMap Premium 8.0; Digital Surf: Besançon, France, 2020.

33. Jacobs, T.D.B.; Junge, T.; Pastewka, L. Quantitative characterization of surface topography using spectral analysis. Surf. Topogr. Metrol. Prop. 2017, 5, 013001. [CrossRef]

34. Martínez, J.F.G.; Nieto-Carvajal, I.; Abad, J.; Colchero, J. Nanoscale measurement of the power spectral density of surface roughness: How to solve a difficult experimental challenge. Nanoscale Res. Lett. 2012, 7, 174. [CrossRef] [PubMed]

35. Gonçalves, E.C.M.; Pinto, E.P.; Ferreira, N.S.; Matos, R.S. Fractal Study of Kefir Biofilms. In Proceedings of the XVIII Brazil MRS Meeting-SBPMat, Camboriú, Brazil, 22-26 September 2019.

36. Kanafi, M.M.; Kuosmanen, A.; Pellinen, T.K.; Tuononen, A.J. Macro- and micro-texture evolution of road pavements and correlation with friction. Int. J. Pavement Eng. 2014, 16, 168-179. [CrossRef]

37. Nečas, D.; Klapetek, P. Gwyddion: An open-source software for SPM data analysis. Open Phys. 2012, 10. [CrossRef]

38. Gao, H.; Qiang, T. Fracture Surface Morphology and Impact Strength of Cellulose/PLA Composites. Materials 2017, 10, 624. [CrossRef]

39. Xia, Y.; Cai, J.; Perfect, E.; Wei, W.; Zhang, Q.; Meng, Q. Fractal dimension, lacunarity and succolarity analyses on CT images of reservoir rocks for permeability prediction. J. Hydrol. 2019, 579, 124198. [CrossRef] 
40. Țălu, Ş.; Abdolghaderi, S.; Pinto, E.P.; Matos, R.S.; Salerno, M. Advanced fractal analysis of nanoscale topography of Ag/DLC composite synthesized by RF-PECVD. Surf. Eng. 2020, 36, 713-719. [CrossRef]

41. De Lucena, L.R.R.; Filho, M.C. Lacunarity as index of evaluation of wind direction in Pernambuco. Rev. Bras. DE Biom. 2019, 37, 95-106. [CrossRef]

42. Pinto, E.; Tavares, W.; Matos, R.; Ferreira, A.; Menezes, R.; Costa, M.; Souza, T.; Ferreira, I.; Sousa, F.; Zamora, R. Influence of low and high glycerol concentrations on wettability and flexibility of chitosan biofilms. Quim. Nova 2018, 41, 1109-1116. [CrossRef]

43. De Oliveira, L.M.; Matos, R.S.; Campelo, P.H.; Sanches, E.A.; Da Fonseca Filho, H.D. Evaluation of the nanoscale surface applied to biodegradable nanoparticles containing Allium sativum essential oil. Mater. Lett. 2020, 275, 128111. [CrossRef]

44. Matos, R.S.; Lopes, G.A.C.; Ferreira, N.S.; Pinto, E.P.; Carvalho, J.C.T.; Figueiredo, S.S.; Oliveira, A.F.; Zamora, R.R.M. Superficial Characterization of Kefir Biofilms Associated with Açaí and Cupuaçu Extracts. Arab. J. Sci. Eng. 2018, 43, 3371-3379. [CrossRef]

45. Nosonovsky, M. Entropy in Tribology: In the Search for Applications. Entropy 2010, 12, 1345-1390. [CrossRef]

46. Aja-Fernandez, S.; Estepar, R.S.J.; Alberola-Lopez, C.; Westin, C.-F. Image Quality Assessment Based on Local Variance. In Proceedings of the 2006 International Conference of the IEEE Engineering in Medicine and Biology Society, 30 August-3 September 2006; pp. 4815-4818.

47. Drăguţ, L.; Eisank, C.; Strasser, T. Local variance for multi-scale analysis in geomorphometry. Geomorphology 2011, 130, 162-172. [CrossRef]

48. Woodcock, C.E.; Strahler, A.H. The factor of scale in remote sensing. Remote. Sens. Environ. 1987, 21, 311-332. [CrossRef]

49. Hothorn, T.; Everitt, B.S. A Handbook of Statistical Analyses Using R; Chapman and Hall/CRC: Boca Raton, FL, USA, 2009; ISBN 9780429146169.

50. Burton, Z.; Bhushan, B. Surface Characterization and Adhesion and Friction Properties of Hydrophobic Leaf Surfaces. In NanoScience and Technology; Springer: Berlin/Heidelberg, Germany, 2006; pp. 55-81.

51. Wang, L.; Zhou, Q. Surface hydrophobicity of slippery zones in the pitchers of two Nepenthes species and a hybrid. Sci. Rep. 2016, 6, 19907. [CrossRef]

52. Haworth, M.; Scutt, C.P.; Douthe, C.; Marino, G.; Gomes, M.T.G.; Loreto, F.; Flexas, J.; Centritto, M. Allocation of the epidermis to stomata relates to stomatal physiological control: Stomatal factors involved in the evolutionary diversification of the angiosperms and development of amphistomaty. Environ. Exp. Bot. 2018, 151, 55-63. [CrossRef]

53. Ramos, G.Q.; Cotta, E.A.; Da Fonseca Filho, H.D. Studies on the ultrastructure in Anacardium occidentale L. leaves from Amazon in northern Brazil by scanning microscopy. Scanning 2016, 38, 329-335. [CrossRef]

54. Cernusak, L.A.; Ubierna, N.; Jenkins, M.W.; Garrity, S.R.; Rahn, T.; Powers, H.H.; Hanson, D.T.; Sevanto, S.; Wong, S.C.; McDowell, N.G.; et al. Unsaturation of vapour pressure inside leaves of two conifer species. Sci. Rep. 2018, 8, 7667. [CrossRef] [PubMed]

55. Laurance, W.F.; Camargo, J.L.C.; Fearnside, P.M.; Lovejoy, T.E.; Williamson, G.B.; Mesquita, R.C.G.; Meyer, C.F.J.; Bobrowiec, P.E.D.; Laurance, S.G.W. An A mazonian rainforest and its fragments as a laboratory of global change. Biol. Rev. 2018, 93, 223-247. [CrossRef]

56. Keronen, P.I.R. Flux and Concentration Measurements of Carbon Dioxide and Ozone in a Forested Environment; Department of Physics, University of Helsinki: Helsinki, Finland, 2017; Volume 204, ISBN 978-952-7091-91-3.

57. Oksanen, E. Trichomes form an important first line of defence against adverse environment-New evidence for ozone stress mitigation. Plant Cell Environ. 2018, 41, 1497-1499. [CrossRef]

58. Freeman, B.C.; Beeattie, G.A. An Overview of Plant Defenses against Pathogens and Herbivores. Plant Health Instr. 2008. [CrossRef]

59. Bi, H.; Kovalchuk, N.; Langridge, P.; Tricker, P.J.; Lopato, S.; Borisjuk, N. The impact of drought on wheat leaf cuticle properties. BMC Plant Biol. 2017, 17, 2-13. [CrossRef]

60. Zeisler, V.; Schreiber, L. Epicuticular wax on cherry laurel (Prunus laurocerasus) leaves does not constitute the cuticular transpiration barrier. Planta 2016, 243, 65-81. [CrossRef] [PubMed]

61. Günzel, R.E.; da Costa Güllich, R.I. Aprendendo Ciências: Ensino e Extensão; Universidade Federal da Fronteira Sul: Chapecó, Brazil, 2018; ISBN 9788568221242.

62. Muller, O.; Cohu, C.M.; Stewart, J.J.; Protheroe, J.A.; Demmig-Adams, B.; Adams, W.W. Association between photosynthesis and contrasting features of minor veins in leaves of summer annuals loading phloem via symplastic versus apoplastic routes. Physiol. Plant. 2014, 152, 174-183. [CrossRef] [PubMed]

63. Hickey, L.J. Classification of the architecture of dicotyledonous leaves. Am. J. Bot. 1973, 60, 17-33. [CrossRef]

64. Dantas, A.R.; Lira-Guedes, A.C.; Mustin, K.; Aparício, W.C.S.; Guedes, M.C. Phenology of the multi-use tree species Carapa guianensis in a floodplain forest of the Amazon Estuary. Acta Bot. Bras. 2016, 30, 618-627. [CrossRef]

65. Adams, W.W.I.; Cohu, C.M.; Muller, O.; Demmig-Adams, B. Foliar phloem infrastructure in support of photosynthesis. Front. Plant Sci. 2013, 4, 194. [CrossRef] [PubMed]

66. Almeida, P.A.; Pinto, E.P.; Filho, H.D.F.; Matos, R.S. Distribution of Microorganisms on Surface of Kefir Biofilms Associated with Açaí Extract Distribution of Microorganisms on Surface of Kefir Biofilms Associated with Açaí Extract. Sci. Amaz. 2019, 8, C10-C18.

67. Ferraro, M.A.N.; Pinto, E.P.; Matos, R.S. Study of the superficial distribution of microorganisms in kefir biofilms prepared with Cupuaçu juice. J. Bioenergy Food Sci. 2020, 07, 1-11. [CrossRef] 
68. Megevand, B.; Lins, L.C.; Duchet-Rumeau, J.; Pruvost, S.; Livi, S.; Gérard, J.-F. Probing nanomechanical properties with AFM to understand the structure and behavior of polymer blends compatibilized with ionic liquids. RSC Adv. 2016, 6, 96421-96430. [CrossRef]

69. Ramos, G.; Cotta, E.; Filho, H.F. Análise Morfológica das Folhas de Anacardium occidentale L. Biota Amazônia 2016, 6, 16-19. [CrossRef]

70. Ramos, G.Q.; Da Fonseca De Albuquerque, M.D.; Ferreira, J.L.P.; Cotta, E.A.; Da Fonseca Filho, H.D. Molhabilidade e Morfologia Da Superfície Da Folha Em Cajueiro Da Amazônia Na Região Norte Do Brasil. Acta Sci. Biol. Sci. 2016, 38, 215-220. [CrossRef]

71. Matos, R.S.; Pinto, E.P.; Ramos, G.Q.; Albuquerque, M.D.D.F.D.; Da Fonseca Filho, H.D. Stereometric characterization of kefir microbial films associated with Maytenus rigida extract. Microsc. Res. Tech. 2020, 83, 1401-1410. [CrossRef]

72. Franco, L.A.; Sinatora, A. 3D surface parameters (ISO 25178-2): Actual meaning of Spk and its relationship to Vmp. Precis. Eng. 2015, 40, 106-111. [CrossRef]

73. Blateyron, F. Characterisation of Areal Surface Texture; Leach, R., Ed.; Springer: Berlin/Heidelberg, Germany, 2013; Volume 9783642364, ISBN 978-3-642-36457-0.

74. Solaymani, S.; Ţălu, Ş.; Nezafat, N.B.; Rezaee, S.; Kenari, M.F. Diamond nanocrystal thin films: Case study on surface texture and power spectral density properties. AIP Adv. 2020, 10, 045206. [CrossRef]

75. Bucur, V. Wood Structural Anisotropy Estimated by Acoustic Invariants. IAWA J. 1988, 9, 67-74. [CrossRef]

76. Whitehouse, D.J. Handbook of Surface and Nanometrology, 2nd ed.; CRC Press: Boca Raton, FL, USA; Taylor \& Francis Group: Boca Raton, FL, USA, 2002; ISBN 9781420034196.

77. Mandelbrot, B.B.; Wheeler, J.A. The Fractal Geometry of Nature. Am. J. Phys. 1983, 51, 286-287. [CrossRef]

78. Matos, R.S.; Ramos, G.Q.; Da Fonseca Filho, H.D.; Ţălu, Ş. Advanced micromorphology study of microbial films grown on Kefir loaded with Açaí extract. Micron 2020, 137, 102912. [CrossRef] [PubMed]

79. Wang, H.; Shi, H.; Li, Y.; Wang, Y. The Effects of Leaf Roughness, Surface Free Energy and Work of Adhesion on Leaf Water Drop Adhesion. PLoS ONE 2014, 9, e107062. [CrossRef]

80. Fernández, V.; Sancho-Knapik, D.; Guzmán-Delgado, P.; Peguero-Pina, J.J.; Gil, L.; Karabourniotis, G.; Khayet, M.; Fasseas, C.; Heredia-Guerrero, J.A.; Heredia, A.; et al. Wettability, Polarity, and Water Absorption of Holm Oak Leaves: Effect of Leaf Side and Age. Plant Physiol. 2014, 166, 168-180. [CrossRef] [PubMed]

81. Figueiredo, S.S. Análise de Superfícies Foliares: Um Estudo Sobre a Entropia Como Parâmetro de Uniformidade Superficial e a Superhidrofobicidade Da Espécie Vegetal Thalia Geniculata (LINEU, 1753); Fundação Universidade Federal do Amapá: Macapá, Brazil, 2015.

82. Burton, Z.; Bhushan, B. Surface characterization and adhesion and friction properties of hydrophobic leaf surfaces. Ultramicroscopy 2006, 106, 709-719. [CrossRef] [PubMed]

83. Ryan, B.J.; Poduska, K.M. Roughness effects on contact angle measurements. Am. J. Phys. 2008, 76, 1074-1077. [CrossRef] 